素酸塩発光体群の中では，シーライト構造を有する $\mathrm{CaWO}_{4}, \mathrm{CaMoO}_{4}$ などのダングステン酸，モリブデン 酸化合物が古くから発光体として知られており, 広く研 究されてきた。 それに対して，この層状化合物の発光特 性の研究はまだはじめたばかりなので，それほどデー夕 が蓄積されていない，今後, 層構造の特徵を利用して, 層に種々の金属イオンをドーピングしたり，層間を金属 イオンや鉝体で修飾することにより，その発光特性に多 様性をあたすことができる可能性がある，また，電子移 動やエネルギー移動などの基礎研究における新しい材料 系になることが期待される.さらには, 光触媒, 光電極, 発光素子などへの応用も考えられる。このように，イオ ン交換能を有するチタンおよびニオブなどの層状酸素酸 化合物を新しい発光体群として浮上させ，層状化合物特 有の性質を生かすよう，これからこの研究を進めていき たい、、ろいろな方面の研究者の方々加見て，応用に 関してなにかで教示を頂ければ幸いである。

本題から話がそれるが, 筆者は学生時代に触媒の研究 を行っていたことから, 電極表面上での触媒作用にす興 味をもっている. 熱触媒反忘と異なる点として, 電極反 応においては, 電極電位をコントロールすることにより， 電極表面に吸着した分子に電子的効果をあたえることが できるところに面白さがある，一般的に，触媒の働きと して反応の速度および選択性を变えることがあげられる. 最近の電極鳋媒作用の現れの典型的な例として, 温室効 果の原因となっている二酸化炭素の電解還元反応がある. この電極反応においては, 電極の種類によって, 二酸化 炭素の還元生成物の選択性が, 一酸化炭素, 蟻酸, 炭化 水素などと顕著に変化する。電極表面上で原子の組替え
が起こる反応を行おうとした場合, 平衡論的かつ速度論 的観点からその反応を見る必要がある，おもに，前者は 電極電位と酸化還元電位との関係に, また, 後者は活性 化エネルギー（過電圧）に関係するとみなすことができ る. 熱力学的に反応が進行する可能性があるかどうかを 判断することはをれほど難しくないが，速度論的に反応 が進行するか，また，何が生成物として得られるかを判 断するのはなかなか容易ではない（少なくとも，筆者に とって).この電極表面上での反応に関して，速度論的 ファクターを大きく支配するのが電極触媒作用であると いえよう。これを明らかにしていくためには，原子レ心゙ ルでの, 電気化学と触媒化学や表面科学との相互理解が 重要であると思われる。これには，原子レベルでの電極 表面の構造㧍上び吸着種・反応中間体の情報を得るため のキャラクタリゼーションが必要であることは言うまで むない，一般に，電極反応は固一液相界面て起こるため, 固一気相界面に比べてin situで測定できる手段が限 られてくる. 現在, 電極表面の構造をみる手段として STM P AFM などがあり，吸着種や反応中間体を見る 分光法として，ラマンや反射IRなどがある．また，exsituではあるが, XPSなどで表面組成をしっかりと把 握しておくことも必要であろう。これらの方法をうまく 組み合せ，電極表面で何が起こっているのかを直接見る ことができれば理想的である。これには，表面構造のはっ きりとわかっている単結晶を用いた研究も重要である. あちろん，ここで述べたことは周知のことではあるが, 筆者む日頃思っていることなので書いてみた。このよう な研究がさらに盛んに行われることを期待し、また、筆 者もなんらかのかたちで貢献していきたい。

\title{
水素吸蔵体上での電極反応の将来： 炭酸ガスの電気化学的還元反応を例として
}

\section{大 川きよみ}

\section{1 緒言}

水素吸蔵体は水素を吸蔵することにより不均一気相反 応における有機化合物の水素化反応に対して高い触媒活 性を示すことが知られている。これは，水素吸蔵体中の 吸蔵水素が気相の水素に比べて反応性が強く, また, 吸 蔵水素が表面吸着反応物之值接速やかに反応するためと

平城 2 年東京大学大学院丁学系研究科修上䛞程修厂 東京大学: ‘学部（宁113 東京都文京区本郷 7-3-1)
考えられている。そこで電気化学反応においてもこのよ うに高い反応性を有する吸蔵水菜を利用して, 炭酸ガス のような分解性の低い分子を効率よく還元できることが 期待される. しかし, 吸蔵水素に着目した水素吸蔵体上 での電気化学的還元に関する研究はこれまでは行われて いなかった，そこで我々は水素吸蔵体として Pdを電極 として用い，水素吸蔵前後で炭酸がス還元に対する電極 触媒活性を還元生成物の生成効率および反応速度から見 
積るとともに，炭酸ガスの電気化学的還元において吸蔵 水素が電極反応によ゙のように関与するかを調べてきた.

また，炭酸ガスの電気化学的還元に特異的な活性を示す $\mathrm{Cu}$ を $\mathrm{Pd}$ 表面に修飾した電極上で，水素吸蔵が修飾電 極の触媒活性にどのような影響を及ぼすかについてを明 らかにしてきた．本稿においては我々の研究結果の概略 を紹介し，さらに水素吸蔵体を電極材料に用いる電極反 応の将来の可能性について言及する。

\section{$2 \mathrm{Pd}$ および Cu 修飾 Pd 電極上での炭酸ガスの 電気化学的還元}

\section{$2.1 \mathrm{Pd}$ 上での炭酸ガス還元 ${ }^{1)}$}

前处理として水素吸蔵を施した水素化 $\mathrm{Pd}$ 電極上にて 炭酸ガスの電気化学的還元を行ったところ, 生成物とし て得られる一酸化炭素やギ酸の生成効率は水素化処理を 行わない場合扰よび吸蔵水素を放出させた後に比べて常 に高かった。 また，各生成物の生成速度も水素吸蔵後に 上昇した。これらの結果から炭酸ガスの電気化学的還元 に対する水素吸蔵の有效性が示された。

水素吸蔵により生成効率や生成速度が增加することの 理由として，炭酸ガスの電気化学的還元反応に対する競 争反応である水素発生が水素吸蔵後に抑制されたことが あげられる．このために相対的に炭酸ガス還元への選択 性が増したものと思われる，また，水菜吸蔵により電極 表面の電極活性が变化し，各生成物の生成反応の活性化 エネルギーが低下したことにより反応速度が上昇した可 能性も考えられる．さらに，吸蔵水素が炭酸ガス還元反 応中間体へ直接攻撃するという新たな反応経路が加わっ たことも考えられる。

\section{$2.2 \mathrm{Cu}$ 修飾 Pd 上での炭酸ガス䢱元 ${ }^{2)}$}

$\mathrm{Cu}$ 修飾 Pd 電極上での炭酸ガス還元では水素吸蔵後 にギ酸の生成効率が $20 \%$ から $70 \%$ へと顕著に上昇する など, 際だった水素吸蔵勃果を示した。これは，修飾さ れた $\mathrm{Cu}$ の層を通して水素が吸藏，放出できるからであ る.このように, $\mathrm{Cu}$ 修飾を施した電極においても水素 吸蔵が有効であった。

\section{3 水素吸蔵体上での新しい電気化学の可能性}

以上のように炭酸ガス還元の電極触媒として水素化 $\mathrm{Pd}$ および $\mathrm{Cu}$ 修飾水素化 $\mathrm{Pd}$ が有効であることが示さ れた. 吸蔵水素が還元反応一直接関与したために吸蔵後 の活性が向上したのであれば, Fig. 1 に示すような固 液界面における新たな電気化学的水素化反応の経路が考 えられる，すなわち，従来の水素化反応が，電極表面上 で吸着水素が吸着反応物質を攻撃するという二次元的な 反応でしかないのに対し, 金属水素化物上では電極表面 に加えて電極内部からの吸蔵水素が反応に関与するとい う三次元反応の可能性が考えられる。その結果として，

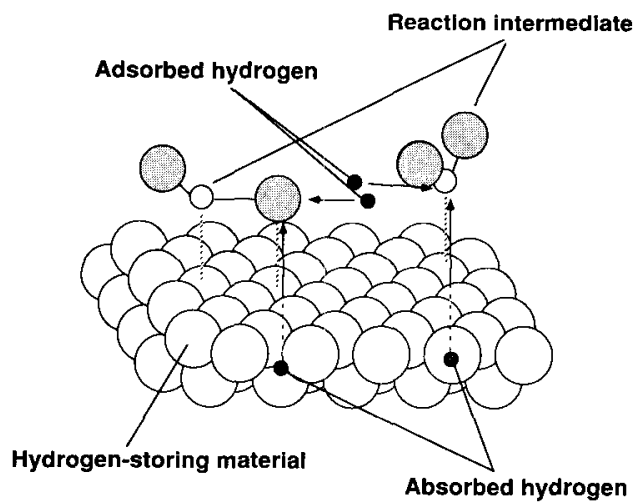

Fig. 1 Possible reaction pathway of the electrochemical hydrogenation on the hydrogenstoring material electrode.

反応速度が上昇することや新たな反応生成物がもたらさ れることが期待できる。 そこで水素吸蔵体として Pd だ けでなく，より優れた水素吸蔵一放出特性を持つ $\mathrm{LaNi}_{5}$, $\mathrm{Mg}_{2} \mathrm{Ni}$ や FeTi などの実用的水素吸蔵合金を電極とし て用いると，より効果的ではないかと思われる，その場 合, 水素の吸蔵一放出に伴う合金の微粉化や，電解質と の接触による劣化をいかに抑えるかが問題となる．この 点を克服するために，まず水素吸蔵合金のアモルファス 化があげられる ${ }^{3)}$.アモルファス化することにより微粉 化が抑えられ，化学的安定性も增す。しかもアモルファ ス相には固溶状態で水素が吸蔵されることや，アモルファ ス合金の表面が結晶表面に比べて活性点が多いために自 身が触媒としても有効であるという利点を持つ. 次に, 微粉化し易い水素吸蔵合金でも $\mu \mathrm{m}$ オーダーの薄膜に することにより微粉化が抑えられることが報告されてい る4．薄膜という形態は，形状の自由度が高く，また積 層構造にすることもできるなど，広範囲な応用が考えら れる.さらに，合金粉末粒子表面に銅メッキを施した後 に圧縮成形して作られるマイクロカプセル化合金は，水 素吸蔵一放出特性を損なわないうえに微粉化しないこと が知られている5 ${ }^{5}$. バインダーとして銅を用いているた めに成形加工が容易で化学的安定性や導伝性が向上する という利点を持っことから，電極として十分に用いるこ とができると思われる。

以上のような手法により様々な水素吸蔵合金を安定な 電極として用いることができ，吸蔵水素を利用した新し い電極反応が期待される．電極触媒として用いるならば, 先に述べたような吸蔵水素による三次元的な効果が期待 される他に，水素吸蔵体上に様々な反応選択性を担う物 質を修飾することにより新しい電極触媒が設計できる。 特にマイクロカプセル化合金はガス拡散電極への応用も 考えられ，高い触媒活性が期待できる．また， $\mathrm{WO}_{3}$ の 
薄膜上にアモルファス $\mathrm{LaNi}_{5}$ 薄膜を形成させて水素化 処理を行うことにより $\mathrm{WO}_{3}$ が着色することが報告され ているが吕，フォトエレクトロクロミック材料之水素吸 蔵体膜とを積層した系に扔いては光照射による着色む期 待できよう，そして，電気的に消色する際に放出される 水素が再び水素吸蔵体中に蓄えられるならば，可逆的な 動作をするフォトエレクトロクロミックデバイスを構築 することも可能である．水素吸蔵体が水素を吸蔵する際 に膨張することを利用して，玨電素子のような微小びず みを生じさせる素子への応用む考えられる。このように， 水素吸蔵体は新たな電極材料として様々な可能性を与え るものと思われる。

\section{文献}

1) K. Ohkawa, K. Hashimoto, A. Fujishima, Y. Noguchi and S. Nakayama, J. Electroanal. Chem., in Press.

2) K. Ohkawa, K. Hashimoto, A. Fujishima, Y. Noguchi and S. Nakayama, The International Symposium on Chemical Fixation of Carbon I)ioxide, Nagoya, Japan Dec. 2-4, 1991.

3) K. Suzuki, J. Less-Common Met., 89, 183 (1983)

4) G. Adachi, K. Niki and J. Shiokawa, J. LessCommon Met., 81, 345 (1981).

5) H. Ishikawa, K. Oguro, A. Kato, H. Suzuki and $I$. Ishii, J. Less-Common Met., 107, 105 (1985)

6) G. Adachi, H. Sakaguchi, T. Shimogohri and J. Shiokawa, J. Less-Common Met., 116, L 13 (1986).

\section{地球環境問題に於ける白金族金属酸化物型 金属電極（DSE）の果たす役割}

\section{DSE 開発経緯と環境問題}

不溶性金属電極, DSE (Dimensionally Stable Electrodeの略）は，1965年にオランダのH. Beer 氏 により発明され，翌 1966 年にイタリアのデ・ノラ社に より商品化され”，我が国に执いては 1969 年より水銀 法食塩電解槽の黑鉛電極（陽極）の代替金属電極として 幅広く且つ急速に，ソーダ電解工業分野にお゙いて 普及した.これはDSE の電槽電圧低減に伴う省エネル ギー, 高電密操業による生産性向上, 長寿命による省力, 不溶性故の製品純度向上等主として $\mathrm{RuO}_{2}$ 系 DSE のそ の類まれなる電極特性が高く評価されたものである。

しかしながら，我が国においては衆知の通り，水俣病 に端を発した水銀環境污染問題から苛性・塩素製法転換 をよざなくされ，1973 年から1987 年にかけて国家的プ ロシェクト規模で食塩電解法も水銀法から隔膜法へ，更 に隔膜法からイオン交換膜法へと世界でも他に例を見な い程の短期間で 2 度に亘る製法転換が行われ今日に至っ ているが,これもDSEに負う所大であったと評価され ている ${ }^{2)}$.

ソーダ電解工業の水銀クローズド化に見られる様に, DSE は図らずも我が国の電解工業における環境污染問 題解決のための草分け的役割を果たした訳であるが, ソー 明和 56 年日本工学院専門学校公害工学科卒業

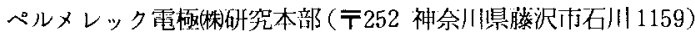

\section{関 本 正 生}

ダプラントでの使用実績が効を奏し，DSE は不溶性金 属電極と言う名称もさることながら, DSEの具備した 電極触媒の形態加白金族金属酸化物型金属電極の代表 として, 塩素発生を伴う水溶液電解反応系は勿論のこと, 最近では鋼板亜鈶めっき，鋼板スズめっき，各種クロム めっき, ステンレス電解酸洗, 電解銅箔製造, 有機酸電 解, 金属電解採取等酸素発生を伴う水溶液電解反応系で の工業的利用も盛んになってきている3

前述の酸素発生を伴う新しい反応系での DSE利用も, 1975 年頃九州電力管内の火力発電所の排煙脱硫装置で 副生する硫酸ナトリウム加らイオン交換膜電解法により 菏性ソーダと硫酸を回収する公害対策電解プラントにお いて, 酸素発生用電極として新たに開発された $\mathrm{IrO}_{2}$ 系 DSE が初めて商業規模で大量に使用されたのが契機と なっており，水銀クローズド化問題と同様に，DSEの 用途開発は環境問題対策の歴史と共にあると言っても過 言ではなく，このような開発経緯を有するDSEが，今 後地球環境問題に対し果たし得る役割について幾つか提 言してみたい.

\section{2 省電力対策}

我々の生活水準の向上と共に電力需要は增加する一方 であり, 今後益々省電力化が問題となるであろう。

電力多消費型産業とされる電解工業における対策とし 